\title{
Identity as a Lens on Livelihoods: Insights from Turkana, Kenya
}

Livelihood surveys often categorise pastoralist households by economic activity and material assets, using measures such as herd ownership, extent of mobility, and the degree of reliance on livestock vs other sources of subsistence and income. However, in contexts of high variability and uncertainty, such objective classifications may inadvertently perpetrate two distortions. First, they stabilise highly fluid economic landscapes, overlooking the ways that people draw opportunistically from an array of livelihood strategies or move between them over time. Second, they may flatten the social field, overlooking the ways that class and kinship structure and constrain people's livelihood options. This paper argues for greater attention to subjective assessments of livelihood, such as the labels by which people selfidentify or distinguish themselves from others. Drawing on over 20 months of anthropological fieldwork, I describe the notion of raiya, a polysemous identity construct that has become a salient part of everyday discourse in Turkana County, Kenya. While raiya connotes an array of conventional dichotomies - including rural/urban, traditional/modern and nomadic/sedentary - attention to the uses of this term in 'speech acts' reveals how it is used to manage relationships and access opportunities across these apparent divisions. This example demonstrates how research on identity practices can inform the study of livelihoods, not only because self-identification indicates a commitment to certain cultural values (Moritz 2012), but also because identity labels highlight the messy processes of boundary-shifting and boundary-crossing that characterise social and economic life under conditions of high variability.

Keywords: Pastoralism, Stratification, Livelihoods, Identity, Methodology 
This paper takes its point of departure from a simple observation: that people may identify culturally as pastoralists even when they do not practice pastoralism as an economic mode of production.

The term 'pastoralist' can be used to indicate a cultural identity and a production/livelihood system, but while the latter implies the former, the former does not always imply the latter... People can identify with a 'pastoral' background without necessarily being involved in pastoral production. Conversely, people can be involved in pastoral production (as traders, investors or even directly as producers) without necessarily sharing a pastoral cultural identity. (Krätli \& Swift 2014: 3)

Due to the seemingly ambiguous connection between subjective self-identification and economic practice, livelihood surveys tend to rely instead on objective measures, such as livestock ownership, extent of mobility, or the degree of reliance (as quantified in calories or income) on resources derived from herds. However, cross-sectional snapshots of material assets and production practices are unlikely to capture the ways that people shift fluidly and opportunistically between an array of livelihood options or the ways that their options are socially differentiated, especially in high variability contexts. In drylands, variability is often characterised in ecological terms as rapid and unpredictable variations in precipitation or vegetation cover (Krätli 2015). This paper relies on a broadened definition that recognises the economic and social repercussions of variability, which is experienced as uncertainty, contingency and precarity.

In this paper, I argue that research on pastoralist livelihood strategies should take greater account of the ways that people self-identify (see also Chang \& Koster 1994; Moritz 2012). This is because the ways that people label themselves and others reflect salient divisions wrought by social change and stratification, which cross-cut livelihood strategies and structure livelihood options.

The paper begins by highlighting the distortions that accompany certain conceptual and methodological approaches used to study of livelihoods. Then, drawing on over 20 months of fieldwork in Turkana, Kenya, I describe the notion of raiya, an identity construct that has become a salient part of everyday discourse in Turkana County, Kenya. This example shows how labelling and identity practices can provide crucial insight into the messy processes of boundary-shifting and boundary-crossing that characterise social and economic life under conditions of high variability. I conclude with some methodological considerations for the study of identity in livelihoods research.

\section{Stabilising Categories \& Polysemous Identities}

Although it is widely recognised that "pastoralism is above all a cultural system" (Blench 2001: 36), many research and policy definitions rely on economic criteria. One of the most common measures is the degree to which a household relies on herd resources (Swift 1984), although a host of other criteria have been used (see Krätli et al. 2015). These measures have been deployed to classify pastoralist "cultures" for comparative anthropological analysis (Lomax et al. 1977), to disaggregate pastoral populations by wealth (Borgerhoff Mulder et al. 2010), and to distinguish households according to livelihood type (Tsegaye et al. 2013; Zampaligré et al. 2014). 
In Turkana County in north-western Kenya, which is the focus of this study, Müller-Dempf describes a range of livelihood activities that includes pastoralists, hybrid pastoralists, periurban hybrid pastoralists and villagers, agro-pastoralists, fishermen, urbanites, and a destitute stratum of "survivors" (2014: 18). The purpose of this typology is to highlight the emerging relations of production between the rural countryside and the expanding towns and settlements, a process of hybridization between pastoralism and other sectors of the economy.

However, such livelihood-based categories create two distortions. First, they stabilise highly fluid economic landscapes, imposing boundaries that are unlikely to capture the relations across or movements between different parts of the system. Or worse, they risk obscuring them. People in drylands respond to variability by shifting opportunistically between strategies, "reinvesting profits from one activity into investments or leaving one job for another" (BurnSilver 2009: 200). Indeed, Müller-Dempf acknowledges that the "the dividing lines [between his proposed livelihood categories] are not clear-cut, and persons may belong to more than one category" (ibid: 24). But unnuanced reliance on livelihood-based classifications imposes the appearance of demographic stability on populations that are actually highly fluid.

The second problem with these livelihood-based categories is that they flatten the social field, obscuring the ways that livelihood options are structured by class stratification. Pastoralism has been described as a family enterprise that is highly reliant on extended networks of relatives as well as non-kin associates (Spencer 1998; Krätli \& Swift 2014: 4). Müller-Dempf recognises the importance of such connections and uses the notion of 'hybridity' to describe collaborations across the pastoral and non-pastoral sectors. However, the livelihood categories upon which he relies emphasise horizontal relations defined by economic cooperation and transaction while largely overlooking (i.e. flattening) the vertical hierarchies that structure those relationships, and which give rise to dependency and exploitation.

Recognising the limitations of economically-oriented approaches to livelihood research, others have recommended that definitions of pastoralism should pay greater attention to the ways that people self-identify (Chang \& Koster 1994: 9; Moritz 2012). However, the relationship between cultural and economic practice is at times ambiguous. As noted above, people sometimes identify as pastoralists even when they have no livestock (Baxter 1994), as reflected in the observation that "even some urban Afar residing in Logia [Ethiopia] still identify as pastoralists" (Schmidt \& Pearson 2016 :28). In an early reflection on this point, Baxter tentatively proposed a distinction among:

1) 'pure pastoralists' who do not cultivate...,

2) Those peoples who perceive themselves as being primarily pastoral but cannot subsist by their stock alone... [and]

3) Those people who are primarily agriculturalists but maintain, at least in their own conception, strong pastoral values... (1975: 207)

More recent scholarship has made similar attempts to resolve this apparent ambiguity between cultural identification and material production. In her study of nomadic pastoralists in Afghanistan, who are generally identified by the term kuchi, de Weijer determines that the persistence of kuchi identity among settled people makes it unfit for analysis:

'Settled kuchi' may still perceive themselves as kuchi and may be represented by the kuchi leaders. In socio-political terms they still form part of the kuchi community. 
However, they are not migratory, and not livestock dependent... The term kuchi, therefore, is commonly used, also by the kuchi themselves, though it is not a practically useful definition. (2007: 10)

In an attempt to provide some clarity, de Weier introduces three sub-categories: 1) those who are migratory and livestock-dependent, 2) those who are settled and livestock-dependent, and 3 ) those who are no longer livestock but still identify as kuchi. However, such categories slip back into the pitfalls of the objective criteria criticised above. Rather than acknowledging the fluid movement across different livelihood activities and the complex relations between different classes, they impose simplistic teleological models of livelihood change. De Weier's typology implies a process of sedentarisation. Similarly, the livelihood types proposed by Müller-Dempf' are based on "a continuum with pastoralism at one end and non-pastoralism at the other" (ibid). Some categories, such the "transitional pastoralist" (Elie 2014), are explicitly liminal.

Such teleological depictions ignore how livelihood transitions can be fluctuating and reversible (Fratkin \& Roth 2005: 9). While processes such as urbanisation, sedentarisation and diversification are often described as uni-directional trends, detailed research often reveals that "the situation on the ground is much more fluid and specific to the situation and individual than this description implies" (BurnSilver 2009: 197). When pastoralists settle or turn to cultivation, it is often as an opportunistic means of capitalizing on new sources of income while ensuring the survival of the herd (Ahmed 2009; Azarya 1993; Homewood et al. 2009; McCabe et al. 2010). Moreover, these processes have different effects on people in different strata, with the wealthy diversifying their investment portfolios to reduce risk while poorer herders turn to urban or agricultural labour for basic subsistence (Little 1985; McCabe et al. 2010).

This paper argues that, despite some ambiguities, the study of pastoralist identity offers crucial insights on the ways that dryland populations perceive and respond to economic transformations and social differentiation. Claims to identity and belonging often reflect historical social divisions, sometimes framing wealth and poverty in moral terms (Anderson $\&$ Broch-Due 1999). Pastoralist identity serves as a site of political struggle, through which gender roles are negotiated (Guyo 2017; Hodgson 2001), governance strategies are exercised and contested (Morton 2010: 19-20), and collective claims for justice are advanced (Cormack 2016; Hodgson 2011; Little 1998; Upton 2014).

However, identity constructs are often polysemous - condensing various connotations and meanings - and cannot be defined in the abstract. Rather they must be understood with attention to the various ways that identity is evoked in particular situations. As Galaty writes of Maasai identity:

Any analysis of the meaning of "Maasai" based on informant glosses will inevitably be limited, leaving untouched those aspects of meaning available to metasemantic discourse, particularly those values embedded in the situation of speech acts. Interpretation should, then, consider senses implicit in the particular contexts in which relevant ethnosociological terms are used. The meaning cannot be derived directly from the word, but rather through the various uses of the word. (Galaty 1982: 5)

The next section illustrates this approach through an ethnographic study of the term raiya, an identity construct that has emerged in the context of Turkana's recent history of development. 


\section{Raiya Identity in Turkana}

When I began fieldwork in February 2015, my objective was to understand the ways that pastoralists in Turkana were experiencing and responding to development interventions. The geographical scope encompassed a transect between the county capital Lodwar and the rural grazelands of Urum. During my first weeks in town, before I had selected a rural field site, Urum was often recommended as a place where an anthropologist could find the "real Turkana", those who live customary lifestyles beyond the county's growing towns and settlements. For many of those accustomed to town life in Lodwar, Urum's residents were regarded as a backward demographic lacking in education and development, but also as custodians of a shared cultural heritage.

It was through these exchanges - mostly in English and Swahili, but with occasional use of my incipient Turkana vocabulary - that I first encountered the term raiya. My urban contacts, nodding as I explained my interest in researching the lives and livelihoods of pastoralists (ng'ikeyokok), would often comment percipiently, "So you want to learn about the raiya?" I was initially perplexed by this term, the meaning of which was difficult to track down. I initially interpreted raiya as a gloss for pastoralists, but I gradually learned that it encompassed a more complex array of meanings.

During my first weeks in town, I learned that raiya is a loanword introduced into the Turkana language from Swahili. The Swahili version of the word is distinguished phonetically from its Turkana variant by the location of the stress ( $r a-I-a$ versus $r a-i-Y A$ ), and I use the spellings raia and raiya to distinguish the Swahili and Turkana variants, respectively. In contemporary Swahili, raia is commonly translated as "citizen". It is derived from Arabic and was used during the pre-colonial period in Zanzibar to refer to the subjects under the authority of the Sultan, broadly encompassing "the lowest common denominator of civic status" (Hunter 2013: 260). During the colonial period, the British government in eastern Africa adopted this word to refer to colonial subjects. Its conventional use was "to describe the people as opposed to the chiefs" (ibid: 266), although the British government also attempted to infuse the term with a notion of civic duty. After independence, the term raia took on the connotation of a more empowered citizenry, in line with the post-colonial government's national ambitions.

However, the meaning of raiya in Turkana diverges strikingly from the Swahili term raia. One theory proposed by friends in town is that before Independence, Turkana-speakers inferred the meaning of the term raia from its practical use by administrative chiefs, which was to distinguish themselves and other agents of the colonial government - including tax collectors and members of colonial military and police units - from the general population. Because most people in Turkana were not Swahili speakers, the connotations of subjecthood did not adhere, and so the Turkana variant took a different pathway of etymological evolution than much of the rest of Swahili-speaking eastern Africa. Rather than the intended notions of subjecthood and subordination, the Turkana variant raiya instead came to refer colloquially to those who saw themselves as living outside the control of government. Even today, rural Turkana communities remain keenly aware of their place on the fringes of the state. This sense of peripherality was most strikingly conveyed by a herder in Urum who defined $n g$ 'iraiya as ng'itunga a nakalipatan ("people on the outside"), as distinguished from those people who live nang'olanyang ("with the government").

However, the meanings and uses of the term raiya have broadened. It no longer distinguishes simply between the Turkana population and the administrative regime of non-Turkana 
"outsiders" (ng'imoe), although this remains relevant in narratives about the marginalisation of Turkana in national politics and in the face of international capitalist penetration (e.g. (McCabe 1994). In its contemporary use, raiya refers to growing divisions within Turkana, between those who uphold custom (etal) and those who have embraced Kenyan modernity, between the urban grids of towns and settlements and the "deep rurals" (Last 1980) of Turkana's grazelands. As such, it signals popular awareness of the social stratification that has accompanied urbanisation, state penetration and development intervention.

In town, the term is used to refer to the rural pasturelands far from Lodwar, as well as the people who inhabit it. It is often applied with a mix of disapproval and respect, signalling what rural people are perceived to lack - education, development, etc. - but also their toughness, courage and self-reliance. As I began research in Urum, I learned that many rural dwellers embrace the term in its more positive connotations, which for them signals a sense of distinction from those who have moved to town, attended school, and forgotten how to survive on the pastoral homestead. This loanword has acquired Turkana nominal affixes to become eraiyait in the singular, and ng'iraiya in the plural; it can also be used adjectivally, as in "that is very raiya!" To be an eraiyait is to have intimate knowledge of livestock and to be accustomed to the trials of life in the remote borderlands.

But one may ask: why not simply rely on existing terms in the Turkana lexicon, distinguishing "herders" (ng'ikeyokok) or "nomads" (ng'ikawotok) from "town-folk" (ng'itunga lu arek)? The reason may have to do with the specificity of these terms.

Grammatically, the terms for herder and nomad are nominalised forms of the verb roots for "to herd" (-yok-) and "to migrate: (-wot-), and their unequivocal denotative meaning leaves little semantic flexibility within which to articulate new ideas. In contrast, the loanword raiya is polysemous, drawing attention to the multi-variate dimensions of emerging social divisions in Turkana, including those conventionally described by such dichotomies as rural-urban, mobile-sedentary, and educated-nonliterate. Raiya identity does not impose rigid categorical boundaries, and so it can be applied with different connotations in different contexts. As Galaty explains in his semantic analysis of Maasai identity:

These usages do not... represent simple markers or fixed and permanent frontiers - the linguistic equivalents of permanent water courses or escarpments which are known to divide two groups. Rather, they resemble the limits established by a grazing herd, which not only moves over time and space, but which may be radically altered as herds are amalgamated or partitioned. (1982: 5)

\section{Identity Shifters \& Boundary Crossers}

As noted above, I initially understood raiya as a gloss for pastoralists. Indeed, raiya identity draws on pastoral ideals, and the young herders with whom I spent time in Urum often described their preference for milk, blood and other pastoral foods. When describing what made them raiya, they remarked that the imported foods (e.g. pasta, rice and leavened bread) and styles of dress found in town don't suit them (nyakajoikinit sua). Instead, they emphasised the attributes required for herding, framed in terms of both knowing (akiyen) deeply about animals as well as being accustomed (anaikin) to hardships. Common comments such as "kinaikini sua akoro" (we are accustomed to hunger) point to their inurement against the trials of life on the remote cattle camps. 
But as I encountered the term in other contexts, I learned that raiya identity is not restricted to herders (ng'ikeyokok). People claiming raiya identity can be found almost anywhere in Turkana, including those engaged primarily in farming (ng'ikatak), fishing (ng'ikecemak) and small-scale trade (ng'imucurus). In Kakuma, women and children living in town gather firewood and produce charcoal sell to customers in the nearby refugee camp. Despite their definitively non-pastoral lifestyles and livelihoods in town, they identify as raiya insofar as they can endure the hot sun and long hours with water, like pastoralists. Many have tended livestock in the past, and some travel periodically to help their rural relatives herding. Others occasionally turn to herding as a source of supplementary income, watching over livestock owned by urban businessmen.

Contested use of raiya as a label reflect shifting boundaries structured by an array of class characteristics, including wealth level, education, values and sensibilities. Urbanites sometimes use the word raiya as a shorthand for "illiterate". When secondary school graduates describe another person as raiya, they are indirectly signalling their own qualifications. But for those who self-identify as raiya, it refers positively to enskilment (Ingold 2000) in the knowledge, skills and sensibilities required for life in the Turkana countryside. As shown in the following example, the raiya label both points to class boundaries and is used to negotiate them, even within families.

During fieldwork, I often visited Lolemagete, a small rural settlement at the end of a dirt track, partway between Uruma and Lodwar. While there, I was often hosted by the family of Joseph, a first-generation urban professional. Joseph's job with a humanitarian NGO takes him abroad to places like Juba, Addis Ababa and even Brussels. His mother Akamais runs a small shop selling dry food items and cooking oil, while also helping her brother Lotom to manage their flock of goats. While Lotom and his agnates own most of the animals, a large portion belongs to Joseph and his mother. Lotom is in charge of the herding labour, Joseph provides cash assistance from his salary and Akamais provides assistance through her business.

Akamais often travels to Lodwar for extended business trips and to visit her sons, often changing her clothes to fit in and visiting a salon to follow the fashions popular in town. On some occasions, as when Lotom migrates to the western highlands during particularly dry seasons, she may even shift completely to urban residence. But upon returning to Lolemagete, she removes her urban garb and dons the tall stack of beads (ng'akoromwa) that identify her as a raiya woman. She retains a solid claim to raiya identity, even as she moves between town and rural life, and this positions her to negotiate the financial terms of herd management with her relatives.

However, Joseph cannot make the same claims to raiya identity, and this affects his relationship with his rural relatives. During one of my visits to Lolemagete, I was taking morning tea with Lotom, when his brother pointed out that their cash was insufficient to buy more food. Lotom nodded, and later that morning we walked to a nearby hill where we could reach phone signal. Lotom wanted to call Joseph -who was in Lodwar - to request financial assistance, which could be sent via M-Pesa mobile transfer. During the call, there was some polite deliberation about the amount to be sent, as Joseph had just recently sent a large transfer of money. But Joseph eventually agreed to send a small transfer. As we ascended the hill, Lotom explained that he and other raiya in Joseph's family had put him through school by selling livestock, which obliged him to send assistance. 
Attention to the ways that raiya is practiced as an identity and applied or withheld as a label provides important insights about the practice of livelihood across Joseph's family. It points to the fluidity by which Akamais moves between urban and rural settings according to the relative opportunities and risks at any given time. Unlike permanent town-dwellers, Akamais's urban presence is more transient, and the same could be said for many other townbased raiya, for whom "urbanisation is often neither definitive nor final" (Stites 2020: 35).

References to raiya identity also highlights how class relations cross-cut kinship relations. While Joseph and his raiya relatives cooperate to grow and support their herd, resources are not shared in a simple collective pool. They are owned by particular individuals or groups, with different prospects for accumulation. While Lotom's investments remain tied to the herd, Joseph can use his salary to purchase land or invest in business in town. The relationship can be mutually beneficial. However, Lotom can also extract additional financial support as reciprocation for the investments that he and other raiya relatives made to Joseph's education.

\section{Conclusions}

Objective measures of material assets and economic activities risk distorting dryland livelihoods by emphasising stability and flattening social complexity. This paper suggests that researchers can avoid these pitfalls by attending to shifting and contested identity practices. Identity may function in dramatically different ways across contexts. Elsewhere, social divisions are reflected in the shifting meanings of ethnicity. Among Maa-speakers, the term ormeek historically referred to non-Maasai Africans, but during the colonial period it became a derogatory label applied to Maasai men who learned Swahili, went to school, and sought employment with the government or in town (Hodgson 1999). It was a way of denying ethnicity to those who did not adhere to a pastoralist way of life. While some accounts describe the denial of Turkana identity to those who lack animals (Broch-Due 1999: 88 ), such exclusion is uncommon today, and it is widely accepted that all who are descended from Turkana parents are "one people" (ng'itunga apei). Therefore, intra-ethnic social differentiation requires a new vocabulary, and the loanword raiya serves this purpose.

As demonstrated in the relationship between Joseph and Lotom, raiya identity references the ways kinship and class relations become intertwined. It also highlights how measures of disparities in material assets may overlook other forms of difference. Raiya identity is less about what you do or own and more about what you know (akiyen) or to what you are accustomed (anaikin). To use Bourdieu's (1986) terminology, raiya distinguishes people by differences in embodied capital, rather than the more visible and measurable differences in material capital that are usually the focus of surveys. Even when one no longer possesses livestock or practices herding, they may retain a pastoralist identity so long as they maintain strong ties with those who do. Arusha Maasai in Tanzania have long practiced agriculture, yet rather than dispensing with the "pastoral cultural hegemony" of Maasai identity, they embraced it and adapted it to their needs (Spear 1993). Among contemporary Maasai women who migrate to towns and cities, those engaged in circular rather than permanent migration for whom social networks back home are more crucial - report a stronger affinity to pastoral values (Jowell et al. 2018). In Syria and Lebanon, those who have turned to farming, migrant labour or other occupations for their income nonetheless "remain Bedouin culturally as long as they maintain close social ties with pastoral kin" (Chatty 2014: 29). 
The terms by which people identity themselves or label others coalesce multiple layers of meaning, and it is due to this polysemy that raiya is such a salient concept in Turkana. Its multiple meanings defy categorical boundaries because the complex identity to which it refers emerged historically in the context of boundary-crossing encounters. It shows that rural urban distinctions may not be useful without acknowledging the difference between permanent urban dwellers and boundary crossers. However, this polysemy may be frustrating to researchers seeking categories of analysis, for whom the concept raiya may seem like an imprecise amalgam of dichotomies. For example, raiya is not simply a gloss for 'pastoralist'; it also encompasses people primarily involved in fishing, farming and even urban trade. Rather than providing classificatory boundaries that divide the world into meaningful parts, it seems to combine and conflate meanings ambiguously.

However, identity constructs cannot be defined in the abstract. The multiple meanings of raiya are derived not from translation or literal interpretation, but from observation of the ways the term is used in situated speech acts. Attention to the ways that identities are imposed on others or attributed to oneself can indicate which social divisions are important in particular contexts, as well as the ways that people contest and cross them. Insights from qualitative study on self-perceived identification can be incorporated into interview questionnaires through appropriate references to the salient dimensions of identity. Of course, a question like "Do you identify as raiya?" might be too direct, lacking both context and sensitivity to norms around labelling. But one might use the term raiya to ask relevant questions about education, herding experience or lifestyle preference. Moreover, the ways that raiya emerges in everyday discourse reveals what differences are most salient in particular contexts.

\section{References}

Ahmed, A. G. M. 2009. 'Transforming Pastoralism: A case study of the Rufa'a Al-Hoi ethnic group in the Blue Nile state of Sudan'. Nomadic Peoples 13: 113-133.

Anderson, D. M. \& V. Broch-Due. 1999. The Poor are Not Us: Poverty and Pastoralism in Eastern Africa. Oxford: James Currey.

Azarya, V. 1993. 'Sedentarization and Ethnic Identity among the Fulbe: A Comparative View'. Senri Ethnological Series 35: 35-60.

Baxter, P. T. W. 1975. 'Some Consequences of Sedentarization for Social Relationships', in Pastoralism in Tropical Africa, ed. T. Monod. London: Oxford University Press. pp. 206-228.

Baxter, P.T.W. 1994. 'Pastoralists are People: Why Development for Pastoralists, not the Development of Pastoralism?' The Rural Extension Bulletin, No. 4. University of Reading: Agricultural Extension and Rural Development Department. pp. 3-8.

Blench, R. 2001. 'You can't go home again': Pastoralism in the new millennium. London: ODI.

Borgerhoff Mulder, M., I. Fazzio, W. Irons, et al. 2010. 'Pastoralism and Wealth Inequality: Revisiting an Old Question'. Current Anthropology 51(1): 35-48.

Bourdieu, P. 1986. 'The Forms of Capital', in Handbook of Theory and Research for the Sociology of Education, ed. J G. Richardson. New York: Greenwood Press. pp. 241258. 
Broch-Due, V. 1999. 'Remembered Cattle, Forgotten People: The Morality of Exchange \& the Exclusion of the Turkana Poor', in The Poor are Not Us: Poverty and Pastoralism in Eastern Africa, eds. D.M. Anderson \& V. Broch-Due. Oxford: James Currey. pp. 50-88.

BurnSilver, S. B. 2009. 'Pathways of Continuity and Change: Maasai Livelihoods in Amboseli, Kajiado District, Kenya', in Staying Massai? Livelihoods, Conservation and Development in East African Rangelands, eds. K. Homewood, P. Kristjanson and P. C. Trench. New York: Springer. pp. 161-207.

Chang, C. \& H. Koster. 1994. Pastoralists at the Periphery: Herders in a Capitalist World. Tucson: University of Arizona Press.

Chatty, D. 2014. 'The Persistence of Bedouin Identity and Increasing Political SelfRepresentation in Lebanon and Syria'. Nomadic Peoples 18(2): 16-33.

Cormack, Z. 2016. "The promotion of pastoralist heritage and alternative "visions" for the future of Northern Kenya'. Journal of Eastern African Studies 10(3): 548-567.

Devereux, S. \& K. Tibbo. 2013. 'Social Protection for Pastoralists', in Pastoralism and Development in Africa: Dynamic Change at the Margins, eds. A. Catley, I. Scoones \& J. Lind. London: Routledge. pp. 215-230.

Elie, S. D. 2014. 'Soqotra's pastoral economy: from core to auxiliary livelihood'. Pastoralism: Research, Policy and Practice 4(15).

Fratkin, E. \& E. A. Roth. 2005. As Pastoralists Settle: Social, Health, and Economic Consequences of the Pastoral Sedentarization in Marsabit District, Kenya. New York: Kluwer Academic-Plenum Publishers.

Galaty, J. G. 1982. 'Being "Maasai:; Being "people-of-cattle": Ethnic shifters in East Africa'. American Ethnologist 9: 1-20.

Guyo, F. B. 2017. 'Colonial and post-colonial changes and impact on pastoral women's roles and status'. Pastoralism 7.

Hodgson, D. L. 1999. 'Once intrepid warriors': modernity and the production of Maasai masculinities. Ethnology 38: 121-50.

Hodgson, D. L. 2001. Rethinking Pastoralism in Africa: Gender, Culture, and the Myth of the Patriarchal Pastoralist. Oxford: James Currey.

Hodgson, D. L. 2011. Being Maasai, Becoming Indigenous. Bloomington: Indiana University Press.

Homewood, K., P. Kristjanson \& P. Trench. 2009. Staying Maasai? Livelihoods, Conservation and Development in East African Rangelands. New York: Springer.

Hunter, E. 2013. 'Dutiful Subjects, Patriotic Citizens, and the Concept of "Good Citizenship" in Twentieth-Century Tanzania'. The Historical Journal 56(1): 257-277.

Ingold, T. 2000. The Perception of the Environment: Essays on livelihood, dwelling and skill. London: Routledge.

Jowell, A., S. Wulfovich, S. Kuyan \& C. Heaney. 2018. 'Ethnic identity, resilience, and wellbeing: a study of female Maasai migrants'. International Journal of Public Health 63: $703-711$.

Krätli, S. (2015) Valuing variability: New Perspectives on climate resilient drylands development. IIED. Edited by de Jode, H. 
Krätli, S., B. Kaufmann, H. Roba, et al. 2015. A house full of trap doors: Identifying barriers to resilient drylands in the toolbox of pastoral development. London and Edinburgh.

Krätli, S. \& J. Swift. 2014. 'Counting Pastoralists' in Kenya. Nairobi: DLCI/REGLAP.

Last, M. 1980. 'Conservative Change', presented at the Conference on Change in Rural Hausaland, February $29^{\text {th }}-$ March $1^{\text {st }}$. Bagauda.

Little, P. D. 1985. 'Social Differentiation and Pastoralist Sedentarization in Northern Kenya'. Africa 55(3): 243-261.

Little, P. D. 1998. 'Maasai Identity on the Periphery'. American Anthropologist 100: 444457.

Lomax, A., C. M. Arensberg, R. Berleant-Schiller, et al. 1977. 'A Worldwide Evolutionary Classification of Cultures by Subsistence Systems'. Current Anthropology 18: 659-708.

McCabe, J. T., P. W. Leslie \& L. DeLuca. 2010. 'Adopting cultivation to remain pastoralists: the diversification of Maasai livelihoods in northern Tanzania'. Human Ecology 38: $321-334$.

McCabe, T. J. 1994. 'The Failure to Encapsulate: Resistance to the Penetration of Capitalism by the Turkana of Kenya', in Pastoralists at the Periphery: Herders in a Capitalist World, eds. C. Chang \& H. Koster. Tucson: University of Arizona Press. pp. 309-327

Moritz, M. 2012. 'Pastoral intensification in West Africa: Implications for sustainability'. Journal of the Royal Anthropological Institute 18: 418-438.

Morton, J. 2010. 'Why Should Governmentality Matter for the Study of Pastoral Development?' Nomadic Peoples 14: 6-30.

Müller-Dempf, H. 2014. Hybrid Pastoralists - Development interventions and new Turkana identities. Max Planck Institute of Social Anthropology Working Paper No. 156, Halle.

Schmidt, M. \& O. Pearson. 2016. 'Pastoral livelihoods under pressure: Ecological, political and socioeconomic transitions in Afar (Ethiopia)'. Journal of Arid Environments 124: $22-30$.

Spear, T. 1993. 'Being "Maasai" but not "People of the Cattle": Arusha Agricultural Maasai in the Nineteenth Century', in Being Maasai: Ethnicity and Identity in East Africa, eds. T. Spear \& R. D. Waller. London: James Currey.

Spencer, P. (1998). The Pastoral Continuum: The Marginalization of Tradition in East Africa. Oxford: Clarendon Press.Stites, E. 2020. "The Only Place to Do This is in Town”: Experiences of Rural-Urban Migration in Northern Karamoja, Uganda'. Nomadic Peoples, 24(1): 32-55.

Swift, J. 1984. West African Pastoral Production Systems. Bamako: ILCA.

Tsegaye, D., P. Vedeld \& S. R. Moe. 2013. 'Pastoralists and livelihoods: a case study from northern Afar, Ethiopia'. Journal of Arid Environments 91: 138-146.

Upton, C. 2014. 'The new politics of pastoralism: Identity, justice and global activism'. Geoforum 54: 207-216.

de Weijer, F. 2007. 'Afghanistan's kuchi pastoralists: Change and adaptation'. Nomadic Peoples 11: 9-37.

Zampaligré, N., Dossa, L. H., \& Schlecht, E. 2014. 'Climate change and variability: 
Perception and adaptation strategies of pastoralists and agro-pastoralists across different zones of Burkina Faso'. Regional Environmental Change 14(2): 769-783. 